\title{
Apakah Empati Mempengaruhi Kepatuhan Pajak?
}

\author{
Joko Sustiyo ${ }^{1^{*}}$, Danang Desta Yudha ${ }^{2}$ \\ Politeknik Keuangan Negara STAN, Badan Pengawasan Keuangan dan Pembangunan \\ jokosustiyo@pknstan.ac.id, danang.desta@bpkp.go.id
}

$\begin{array}{ll}\text { *Corresponding } & \text { Author } \\ \text { Diajukan } & : \text { 1 Desember } 2021 \\ \text { Disetujui } & : \text { 20 Desember } 2021 \\ \text { Dipublikasi } & : \text { 2 Januari } 2022\end{array}$

\begin{abstract}
Research on the impact of empathy as a non-economic factor on taxpayer compliance has not been studied in Indonesia. Most research still focuses on economic factors that affect tax compliance. To find out whether empathy affects tax compliance, this study uses binary logistic regression analysis because the dependent variable is nominal and categorical. The significance of the regression equation parameters was tested by the Ratio Likelihood Test and the Wald Test. Then, the goodness of fit model was tested using the Hosmer-Lemeshow Test. The likelihood ratio test shows that there is at least one coefficient from the regression model that has an effect on the 5\% significance level. Based on the Wald test, there is no independent variable that has a significant effect on tax compliance with a $5 \%$ significance level. The Hosmer-Lemeshow test states that the binary logistic regression model in this study is feasible to use. Binary logistic regression analysis shows that only one predictor has a significant effect on the tax compliance variable, namely empathic concern items. The odds ratio value of 1.054 on the empathic concern items variable shows that taxpayers who have empathy will be 1.054 times more tax compliant than respondents who do not have empathy. In other words, respondents who have empathy will tend to be more obedient in paying taxes than those who do not have this trait. Therefore, the government can formulate regulations that support the emergence of empathic concern items in the community so that tax compliance increases.
\end{abstract}

Keywords: taxation; tax compliance; empathy; binary logistic regression; empathic concern

\section{PENDAHULUAN}

Penerimaan pajak sebagai tulang punggung pendapatan negara merupakan hal yang umum di semua negara di dunia, termasuk Indonesia. Pada tahun 2020, dari total pendapatan Indonesia sebesar $\mathrm{Rp} 1.633,6$ triliun, porsi terbesar merupakan penerimaan pajak yaitu sebesar $\mathrm{Rp} 1.069,97$ triliun atau $62,95 \%$ dari total pendapatan negara (Direktorat Jenderal Pajak, 2021). Hal ini menguatkan bahwa pajak memiliki kontribusi yang sangat besar bagi penerimaan suatu negara.

Mengingat pentingnya peningkatan penerimaan negara dari sektor pajak, para peneliti mencari tahu bagaimana hubungan kesadaran wajib pajak terhadap kepatuhan pembayaran pajak. Penelitianpenelitian tersebut menyimpulkan bahwa kesadaran wajib pajak memiliki pengaruh yang positif dan signifikan terhadap kepatuhan pajak (Malau, Gaol, Giawa, \& Juwita, 2021; Pawama, Sondakh, \& Warongan, 2021; Saleh, Rukmana, \& Rahayu, 2021; Siregar, 2017; Sularsih \& Wikardojo, 2021; Wardani \& Rumiyatun, 2017). Dengan demikian, apabila wajib pajak sadar akan pentingnya membayar pajak, kepatuhan mereka dalam membayar pajak juga akan semakin tinggi yang akhirnya akan meningkatkan penerimaan negara di bidang pajak.

Kesadaran pajak merupakan situasi dimana wajib pajak mengetahui dan memahami cara menghitung dan membayar kewajiban pajaknya mereka secara sukarela (Andreas and Savitri, 2015). Ariyanto, et al. (2020) menyatakan bahwa wajib pajak yang paham arti dan pentingnya pajak bagi perekonomian akan lebih menyadari pentingnya pembayaran pajak. Argumen ini dikuatkan oleh Manual and Xin (2016) yang menyatakan bahwa wajib pajak yang memiliki literasi perpajakan akan lebih patuh dalam membayar pajak. 
Kesadaran pajak dapat mempengaruhi kepatuhan pembayaran pajak. Hal ini memiliki implikasi pemungutan pajak dapat dilakukan secara lebih maksimal apabila wajib pajak memiliki kesadaran pajak. Kesimpulan tersebut sejalan dengan hasil penelitian Sumartaya and Hafidiah (2014) yang menyebutkan bahwa kesadaran pajak dan moral pajak berpengaruh secara signifikan terhadap ketidakpatuhan pajak. Selain itu, Kamil (2015) membuktikan bahwa kesadaran pajak, pengetahuan perpajakan dan pelayanan otoritas pajak berpengaruh secara positif dan signifikan terhadap kepatuhan pajak.

Berdasarkan penjabaran di atas, hasil penelitian tentang kesadaran pajak yang berpengaruh secara positif terhadap kepatuhan pajak telah banyak dilakukan oleh para peneliti di Indonesia. Kesimpulan mereka hampir seragam bahwa kepatuhan pajak dapat ditingkatkan dengan meningkatkan kesadaran pajak wajib pajak. Peningkatan kesadaran tersebut biasanya dilakukan melalui sosialisasi dan edukasi dari DJP bahwa pajak itu penting bagi penerimaan negara dan dapat digunakan untuk membangun ekonomi Indonesia. Peningkatan kepatuhan pajak tersebut fokus pada sisi eksternal wajib pajak.

Penelitian ini melihat kepatuhan pajak wajib pajak di Indonesia dari perspektif yang berbeda. Sisi internal wajib pajak, dalam hal ini adalah empati, ternyata memiliki dampak yang positif terhadap kepatuhan wajib pajak (Calvet \& Alm, 2017). Mereka menyimpulkan bahwa wajib pajak yang memiliki sifat empati yang tinggi akan lebih patuh dalam pembayaran pajak. Penelitian dari perspektif ini belum ada di Indonesia sehingga penulis tertarik untuk meneliti apakah empati wajib pajak akan mempengaruhi kepatuhan pajak mereka dalam membayar pajak.

Penelitian ini ditujukan untuk menganalisis pengaruh empati terhadap kepatuhan pajak. Secara akademis penelitian ini menguji model penelitian Calvet and Alm (2017) yang menyatakan bahwa perilaku empati berdampak positif pada kepatuhan pajak di Amerika Serikat. Penelitian ini ingin mengetahui apakah model tersebut juga berlaku di Indonesia.

Secara praktis penelitian ini diharapkan dapat memberikan dasar dalam pengambilan keputusan di Kementerian Keuangan, khususnya Direktorat Jenderal Pajak, terkait kepatuhan pajak. Penegakan hukum sebagai salah satu cara untuk meningkatkan kepatuhan pajak dapat dilengkapi dengan kebijakan-kebijakan non ekonomi (berupa empati) berdasarkan penelitian ini.

\section{STUDI LITERATUR}

Empati telah menjadi objek penelitian selama beberapa dekade. Para peneliti melihat empati dalam berbagai aspek. Sebelumnya, sisi afektif empati dapat menjelaskan bagaimana "berbagi" emosi terjadi (Lipps and Sanborn, 1926; McDougall, 1908). Selanjutnya, aspek kognitif empati menjadi perhatian para peneliti yang dimulai oleh Mead (1934) dan Piaget (1932). Dari sisi aspek kognitif, empati dijelaskan sebagai perasaan kita seolah-olah mengalami perasaan orang lain (Davis, 1983).

Keragaman konseptual empati disebabkan oleh perbedaan dimensi yang diteliti, diantaranya empati sebagai katalis, fungsi, proses, hasil, afektif, kognitif, keterlibatan diri dan orang lain, mengarah ke perilaku, dan yang terjadi dalam konteks tertentu (Guthridge and Giummarra, 2021). Berdasarkan penelitian meta-analisis mereka, empati merupakan keadaan seseorang yang mengalami sisi afektif dan kognitif orang lain tetapi masih mempertahankan jati diri asli mereka. Oleh karena itu, empati dapat diukur secara multidimensi menggunakan multidimensional individual difference measure of empathy (Davis, 1983). Penggunaan ukuran tersebut masih relevan karena banyak digunakan oleh penelitan lain sampai saat ini (diantaranya Calvet and Alm, 2017; Edina, 2020; Moreno-Poyato and Rodríguez-Nogueira, 2021; Nugrahani and Andriani, 2020).

Davis (1983) menyatakan ada 4 (empat) kelompok item dalam empati, diantaranya fantasy items, perspective-taking items, empathic concern items, dan personal distress items. Fantasy items merupakan kecenderungan manusia untuk mengidentifikasi karakter tidak nyata yang ada dalam buku, film, atau drama secara kuat. Perspective-taking items menunjukkan kemampuan manusia untuk berpikir menggunakan sudut pandang orang lain. Empathic concern items menjelaskan perasaan manusia yang hangat, memiliki kasih sayang dan peduli terhadap pengalaman buruk orang lain. Personal distress items menunjukkan perasaan tidak nyaman apabila melihat pengalaman negatif orang lain. 
Kepatuhan wajib pajak merupakan suatu keadaan dimana wajib pajak secara sadar membayar pajak. Dalam penelitian ini, wajib pajak dianggap patuh sesuai kriteria dalam PMK Nomor 39/PMK.03/2018 tentang Tata Cara Pengembalian Pendahuluan Kelebihan Pembayaran Pajak. Sesuai dengan pasal 3 (2), wajib pajak disebut patuh apabila

a. tepat waktu dalam menyampaikan SPT;

b. tidak mempunyai tunggakan pajak untuk semua jenis pajak, kecuali tunggakan pajak yang telah memperoleh izin mengangsur atau menunda pembayaran pajak;

c. laporan keuangan diaudit oleh akuntan publik atau lembaga pengawasan keuangan pemerintah dengan pendapat wajar tanpa pengecualian selama 3 (tiga) tahun berturut-turut; dan

d. tidak pernah dipidana karena melakukan tindak pidana di bidang perpajakan berdasarkan putusan pengadilan yang telah mempunyai kekuatan hukum tetap dalam jangka waktu 5 (lima) tahun terakhir.

Dalam penelitian ini, wajib pajak dikatakan patuh apabila poin a, b, dan d terpenuhi. Poin c tidak menjadi bahan pertimbangan karena responden dalam penelitian ini adalah wajib pajak orang pribadi yang tidak membuat laporan keuangan.

Hasil penelitian sebelumnya dilakukan oleh Calvet and Alm (2017) yang menyatakan bahwa empati dan simpati mempengaruhi kepatuhan pajak. Mereka juga menyimpulkan bahwa semakin tinggi simpati dan empati, preferensi moral meningkat dan penghindaran pajak menurun. Penelitian terkait kepatuhan pajak yang melibatkan empati belum ditemukan di Indonesia.

Berdasarkan teori dan penelitian sebelumnya, hipotesis dalam penelitian ini adalah:

$\mathrm{H}_{0}$ : fantasy items, perspective-taking items, empathic concern items, dan personal distress items cenderung tidak mempengaruhi kepatuhan pajak

$\mathrm{H}_{1}$ : fantasy items, perspective-taking items, empathic concern items, dan personal distress items cenderung mempengaruhi kepatuhan pajak

Penelitian ini menggunakan analisis regresi logistik biner. Apabila $\mathrm{H}_{0}$ ditolak, $\mathrm{H}_{1}$ akan diterima yang akan memberi kesimpulan bahwa fantasy items, perspective-taking items, empathic concern items, dan personal distress items cenderung mempengaruhi kepatuhan wajib pajak dalam membayar kewajiban pajaknya.

\section{METODE}

Penelitian ini menggunakan pendekatan kuantitatif. Tahapan pertama akan dilakukan secara deskripsi terhadap data penelitian yang telah didapatkan. Selanjutnya, data akan dianalisis menggunakan analisis regresi logistik biner untuk mengetahui apakah ada pengaruh prediktor terhadap variabel respon. Sebelum di-regress, instrumen penelitian akan diuji signifikansinya dengan uji rasio likelihood, uji Wald, dan uji Hosmer-Lemeshow.

Objek penelitian ini adalah faktor multidimensi empati yang mempengaruhi kepatuhan pajak. Multidimensi empati yang dimaksud terdiri dari 4 (empat) dimensi kelompok, yaitu fantasy items, empathic concern items, perspective-taking items, dan personal distress items.

Responden diambil secara acak kepada para wajib pajak yang masih aktif melaporkan SPT Tahunan. Pengambilan sampel diharapkan dapat merepresentasikan wajib pajak di Indonesia.

Data penelitian merupakan data primer yang dikumpulkan melalui kuesioner secara online. Responden menjawab pertanyaan secara langsung di zoho.com. Kuesioner tersebut merupakan gabungan dari kuesioner yang telah digunakan dalam penelitian sebelumnya.

Variabel bebas diambil dari kuesioner Davis (1983) terkait pengukuran empati dalam beberapa dimensi. Ukuran tersebut masih dipakai dalam penelitian tentang empati sampai saat ini (Calvet and Alm, 2017; Moreno-Poyato and Rodríguez-Nogueira, 2021; Nugrahani and Andriani, 2020; dan Edina, 2020). Kuesioner tersebut telah disesuaikan dengan kondisi di Indonesia pada saat ini.

Variabel terikat merupakan kepatuhan pajak. Kepatuhan tersebut diukur secara mandiri oleh responden melalui pertanyaan-pertanyaan kuesioner berdasarkan PMK Nomor 39/PMK.03/2018 tentang Tata Cara Pengembalian Pendahuluan Kelebihan Pembayaran Pajak pasal 3 (2) poin a, b, dan d. Wajib pajak dikatakan patuh dalam penelitian ini apabila wajib pajak tepat waktu dalam 
menyampaikan SPT; tidak mempunyai tunggakan pajak untuk semua jenis pajak, kecuali tunggakan pajak yang telah memperoleh izin mengangsur atau menunda pembayaran pajak; dan tidak pernah dipidana karena melakukan tindak pidana di bidang perpajakan berdasarkan putusan pengadilan yang telah mempunyai kekuatan hukum tetap dalam jangka waktu 5 (lima) tahun terakhir.

Populasi dalam penelitian ini adalah wajib pajak orang pribadi di Indonesia. Teknik pengambilan sampel adalah simple random sampling. Metode sampel tersebut mengambil sampel secara acak dari populasi tanpa mempertimbangkan strata dalam populasi.

Sekaran and Bougie (2016) menjelaskan cara menentukan jumlah sampel yang dibutuhkan, yaitu

a. ukuran sampel berkisar dari 30 responden sampai dengan 500 responden,

b. jumlah minimal sampel adalah 10 kali atau lebih dari jumlah variabel dalam penelitian,

c. jumlah minimal sampel adalah 30 per bagian apabila sampel dibagi dalam kategori (contohnya laki-laki dan perempuan).

Jumlah variabel terikat dalam penelitian ini adalah 1 variabel dengan 4 variabel bebas (total 5 variabel). Berdasarkan cara penentuan ukuran sampel di atas, jumlah responden sebagai sampel yang dibutuhkan dalam penelitian ini adalah minimal 50 wajib pajak orang pribadi.

Variabel dependen pada penelitian ini adalah kepatuhan wajib pajak dalam membayar pajak yang menggunakan data nominal (nilai 1 untuk patuh, nilai 0 untuk tidak patuh). Kepatuhan maupun ketidakpatuhan tersebut ditentukan secara self-assesment berdasarkan kriteria patuh menurut PMK Nomor 39/PMK.03/2018 tentang Tata Cara Pengembalian Pendahuluan Kelebihan Pembayaran Pajak pasal 3 (2) poin a, b, dan $d$.

Variabel independen dalam penelitian ini adalah empati yang skalanya data ordinal. Ukuran empati terdiri dari 4 dimensi pengukuran (Davis, 1983), yaitu fantasy items, empathic concern items, perspective-taking items, dan personal distress items. Variabel tersebut diukur menggunakan skala Likert 5, dari angka 1 yang menyatakan "Sangat Tidak Setuju" sampai dengan angka 5 yang menyatakan "Sangat Setuju". Responden diminta untuk memilih jawaban yang paling menggambarkan mereka.

Berdasarkan landasan teori dan hipotesis sebelumnya, model Analisis Regresi Logistik Biner adalah sebagai berikut.

\section{Keterangan:}

$$
\log \left[\frac{P}{1-P}\right]=\beta_{0}+\beta_{1} \mathrm{~F}+\beta_{2} \mathrm{E}+\beta_{3} \mathrm{P}+\beta_{4} \mathrm{D}+\mathrm{e}
$$

$\mathrm{P} \quad$ : Peluang wajib pajak memiliki kepatuhan pajak yang lebih tinggi

1-P : Peluang wajib pajak memiliki kepatuhan pajak yang lebih rendah

$\beta_{0}:$ Konstanta

$\beta_{1}$ : Koefisien regresi fantasy items

$\beta_{2}$ : Koefisien regresi empathic concern items

$\beta_{3}$ : Koefisien regresi perspective-taking items

$\beta_{4}$ : Koefisien regresi personal distress items

$\mathrm{F}$ : Variabel independen fantasy items

E : Variabel independen empathic concern items

$\mathrm{P} \quad$ : Variabel independen perspective-taking items

D : Variabel independen personal distress items

e : error

Data yang digunakan dalam penelitian ini adalah data primer yang berasal dari kuesioner. Oleh karena itu, instrumen kuesioner harus diuji terlebih dahulu untuk memastikan keakuratannya dalam mengukur variabel (Sekaran and Bougie, 2016). Pengujian dilakukan melalui uji reliabilitas (untuk mengukur sejauh mana hasil pengukuran dapat konsisten apabila dilakukan berulang kali pada sampel yang berbeda) dan uji validitas (untuk mengukur sejauh mana alat ukur tersebut dapat mengukur sampel sesuai ukuran sampel tersebut).

Pembahasan hasil penelitian dimulai dengan analisis deskriptif. Analisis ini deskriptif menggambarkan statistik variabel terikat dan variabel bebas yang mencakup nilai maksimal, nilai 
minimal, nilai rata-rata, dan standar deviasi. Hal ini dilakukan untuk menjelaskan karakteristik sampel secara umum.

Setelah itu, langkah selanjutnya adalah menguji signifikansi parameter pada model regresi logistik biner (Agresti, 2003), yaitu

1. Uji Rasio Likelihood

Uji ini dilakukan untuk membandingkan model yang mengandung prediktor dengan yang tidak mengandung prediktor. Hipotesis uji rasio sebagai berikut.

$\mathrm{H}_{0}: \beta_{0}=\beta_{1}=\ldots .=\beta_{\mathrm{p}}=0$

$\mathrm{H}_{1}$ : salah satu koefisien $\beta_{\mathrm{i}} \neq 0$ dengan $\mathrm{i}=1,2,3, \ldots, \mathrm{p}$

Skor yang digunakan adalah sebagai berikut.

$$
\mathrm{G}=-2 \ln \left(\frac{\text { likelihood tanpa variabel independen }}{\text { likelihood dengan variabel independen }}\right)
$$

Nilai $\mathrm{G}$ adalah distribusi Chi-square yang memiliki derajat bebas $\mathrm{p}$. Taraf nyata adalah $\alpha$. Dengan demikian, $\mathrm{H}_{0}$ ditolak jika $G \geq X_{(\alpha, \mathrm{p})}^{2}$. Apabila $\mathrm{H}_{0}$ ditolak, paling tidak satu prediktor akan signifikan.

2. Uji Wald

Uji Wald untuk mengetahui pengaruh setiap prediktor terhadap variabel respon. Hipotesis uji Wald sebagai berikut.

$\mathrm{H}_{0}: \beta_{\mathrm{i}}=0$ dengan $\mathrm{i}=1,2,3, \ldots, \mathrm{p}$

$\mathrm{H}_{1}: \beta_{\mathrm{i}} \neq 0$ dengan $\mathrm{i}=1,2,3, \ldots, \mathrm{p}$

Skor yang digunakan adalah sebagai berikut.

$$
W=\left[\frac{\beta \mathrm{i}}{\mathrm{SE}(\beta \mathrm{i})}\right]^{2}
$$

Ukuran $\mathrm{W}$ adalah distribusi Chi-square yang derajat bebasnya 1 . Nilai $\alpha$ adalah tingkat signifikansi. Dengan demikian, $\mathrm{H}_{0}$ ditolak apabila $\mathrm{W} \geq X_{(\alpha, 1)}^{2}$.

\section{Uji Goodness of fit test}

Uji ini dilakukan untuk mengetahui kesesuaian persamaan regresi logistik biner yang telah disusun (Hosmer, Lemeshow, and Sturdivant, 2013) menggunakan Hosmer-Lemeshow Test. Hipotesisnya adalah sebagai berikut.

$$
\begin{aligned}
& \mathrm{H}_{0}: X^{2}{ }_{\mathrm{HL}}=X^{2}{ }_{(\mathrm{g}-2)} \\
& \mathrm{H}_{1}: X^{2}{ }_{\mathrm{HL}} \geq X^{2}{ }_{(\mathrm{g}-2)}
\end{aligned}
$$

Skor $X^{2}{ }_{\mathrm{HL}}$ merupakan distribusi chi-square Hosmer-Lemeshow berdasarkan output SPSS yang dibandingkan dengan nilai $X_{(\mathrm{g}-2)}^{2}$ (skor tabel). Kriteria penilaian adalah $\mathrm{H}_{0}$ ditolak jika $X^{2}{ }_{\mathrm{HL}} \geq X_{(\mathrm{g}-2)}^{2}$.

Penelitian akan dilanjutkan dengan analisis regresi logistik biner setelah uji signifikansi dilakukan. Regresi logistik ini digunakan karena variabel respon bersifat dikotomis (Hosmer, Lemeshow, and Sturdivant, 2013b). Analisis regresi ini digunakan untuk mengetahui hubungan variabel bebas yang bersifat biner dengan variabel terikat yang bersifat kategoris (Chambers, 1996).

Pengolahan data pada penelitian ini menggunakan aplikasi Microsoft Excel 2019. Setelah itu, hasil olahan data akan diuji menggunakan SPSS 25 untuk mengetahui pengaruh empati terhadap kepatuhan pajak. Laporan penelitian disusun menggunakan Microsoft Word 2019.

\section{HASIL}

Data penelitian bersumber dari jawaban 238 responden yang merupakan wajib pajak. Data kepatuhan pajak sebagai variabel terikat berupa data yang berskala nominal. Variabel selanjutnya adalah variabel bebas yang merupakan data berskala ordinal tentang sifat empati dengan 4 (empat) dimensinya dari masing-masing responden. Gambaran secara umum responden akan dilakukan menggunakan analisis deskriptif.

Grafik 1 memperlihatkan variasi latar belakang responden. Jangka waktu responden menjadi wajib pajak dari 1 tahun sampai dengan 46 tahun. Jangka waktu paling lama responden perempuan yang menjadi wajib pajak adalah 40 tahun sebanyak 1 orang, sedangkan responden laki-laki adalah 46 
tahun sebanyak 1 orang. Responden yang baru 1 tahun menjadi wajib pajak sejumlah 6 orang. Kebanyakan responden laki-laki telah menjadi wajib pajak selama 10 sampai dengan 20 tahun. Berbeda dengan responden perempuan, mayoritas dari mereka menjadi wajib pajak dari 5 sampai dengan 12 tahun.

Berikut adalah gambaran lama waktu responden menjadi wajib pajak berdasarkan jenis kelamin.

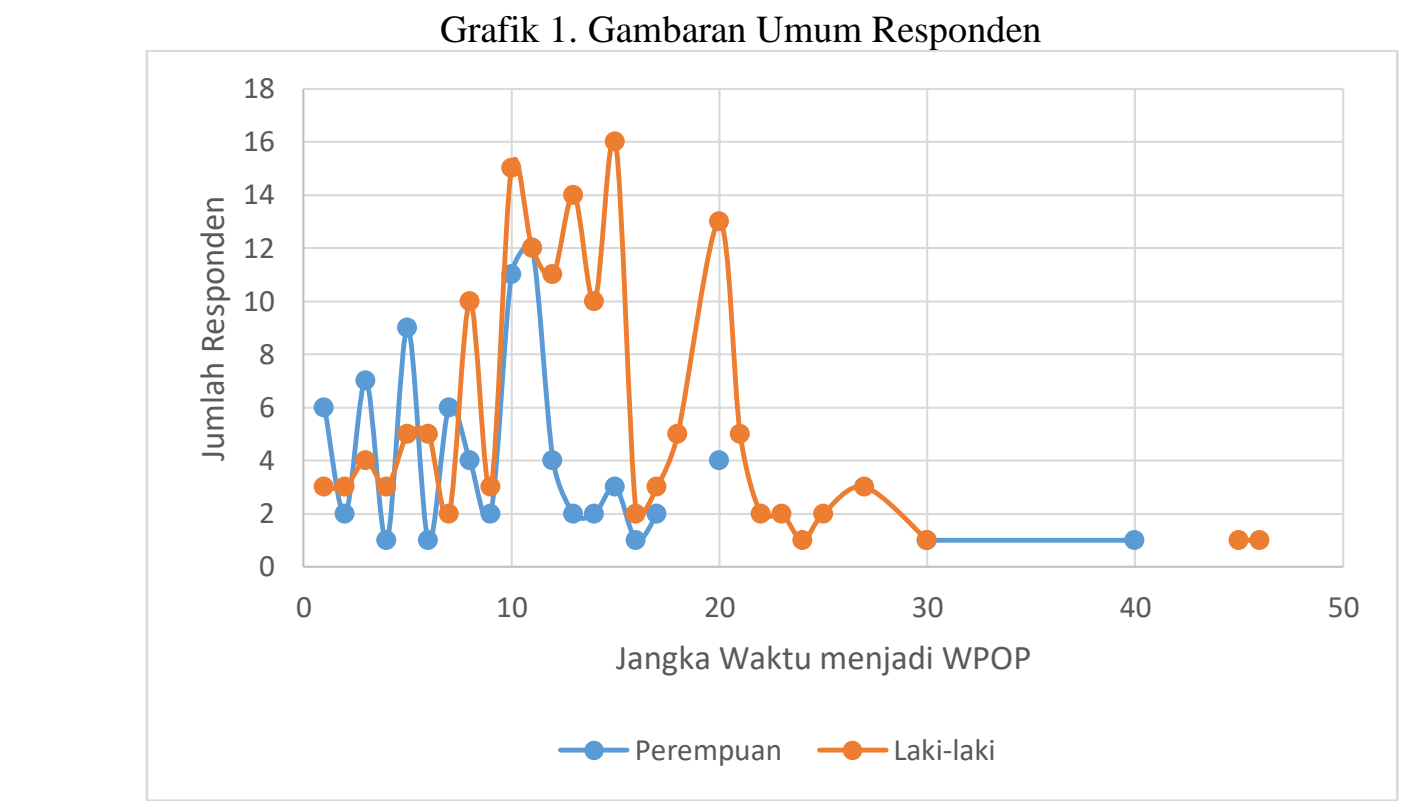

Sumber data: hasil olahan penulis

Karakteristik empati dan kepatuhan wajib pajak ditunjukkan pada tabel berikut ini.

Tabel 1. Gambaran Kepatuhan Pajak dan Empati

\begin{tabular}{|c|l|l|l|l|l|l|}
\hline \multicolumn{2}{|l|}{} & Patuh & $\mathrm{F}$ & $\mathrm{P}$ & $\mathrm{E}$ & $\mathrm{D}$ \\
\hline \multirow{2}{*}{$\begin{array}{l}\text { Jumlah } \\
\text { Responden }\end{array}$} & Valid & 238 & 238 & 238 & 238 & 238 \\
\cline { 2 - 7 } & Missing & 0 & 0 & 0 & 0 & 0 \\
\hline Mean & .9160 & 28.2479 & 32.7815 & 53.3109 & 30.2563 \\
\hline Std. Deviation & .27802 & 6.33335 & 4.90270 & 8.19617 & 5.45073 \\
\hline Minimum & .00 & 12.00 & 13.00 & 21.00 & 15.00 \\
\hline \multicolumn{2}{|l|}{ Maximum } & 1.00 & 45.00 & 45.00 & 70.00 & 47.00 \\
\hline
\end{tabular}

Sumber data: output SPSS 25

Tabel 1 memperlihatkan responden sejumlah 238 orang. Variabel kepatuhan pajak terdiri dari nilai 1 yang menunjukkan WP patuh dan 0 yang menunjukkan WP tidak patuh. Nilai rata-rata variabel tersebut adalah 0.916 yang berarti $91,6 \%$ responden patuh dalam membayar pajak. Standar deviasi kepatuhan pajak sebesar 0,278 memperlihatkan sebaran data yang kecil.

Untuk variabel independen, nilai minimal untuk fantasy items adalah 12 dan nilai maksimalnya 45 , kemudian nilai rata-ratanya adalah 28,25 . Sedangkan untuk empathic concern items, nilai minimal sebesar 21 dan maksimal 70 dengan nilai rata-ratanya adalah 53,31. Variabel perspective-taking items memiliki nilai minimal, nilai maksimal, dan rata-rata adalah masing-masing 13, 45, dan 32,78. Sedangkan untuk personal distress items, nilai minimal 13 , nilai maksimal 45 , dan nilai rata-rata 32,78. Nilai minimal, maksimal, dan rata-rata yang paling besar berada pada empathic concern items karena jumlah pertanyaan item tersebut paling banyak daripada item lain, yaitu 14 butir pertanyaan.

Kemudian, kuesioner diuji kualitas instrumen yang berupa butir-butir pertanyaan. Uji validitas dilakukan pada semua butir pertanyaan kuesioner menggunakan SPSS melalui Uji Korelasi Product Moment dari Pearson. Item pertanyaan dites hubungannya dengan nilai totalnya. Item dikatakan valid 
apabila nilai korelasi (R) lebih dari 0,127 (skor R tabel dengan jumlah sampel 238 dengan tingkat signifikansi 5\%, df-2). Butir pertanyaan yang $\mathrm{R}$ hitungnya kurang dari 0,126 akan dihapus karena dianggap tidak valid.

Berdasarkan output SPSS pada lampiran 1, hampir semua pertanyaan bernilai R total di atas 0,127 kecuali pertanyaan nomor 9 (d9) pada variabel personal distress items. Oleh karena itu, jawaban pada item tersebut disingkirkan kemudian diuji validitasnya lagi. Setelah uji yang ke-dua, ternyata masih ada pertanyaan yang tidak valid yaitu pada poin 10 (d10). Setelah pertanyaan d10 dihapus, variabel personal distress items diuji lagi dan menghasilkan $\mathrm{R}$ total di atas $\mathrm{R}$ tabel. Dengan demikian, semua pertanyaan dianggap valid.

Uji selanjutnya adalah uji reliabilitas untuk mengetahui kehandalan butir pertanyaan kuesioner. Hal ini untuk memastikan apakah alat ukur konsisten tidak apabila ditanyakan pada kelompok sampel lain. Penelitian ini menggunakan metode Cronbach's Alpha untuk menguji realibilitas kuesioner. Item pertanyaan dianggap reliabel jika nilai $r$ hitung lebih besar dari $r$ tabel (tingkat signifikansi sebesar $5 \%$ ). Berdasarkan lampiran 2, nilai $\mathrm{r}$ hitung adalah 0,834 dengan jumlah pertanyaan sebanyak 44 butir. Nilai $r$ tabel dengan sampel sejumlah 238 adalah 0,127 . Dengan demikian seluruh item pertanyaan dikatakan reliabel karena $r$ hitung lebih besar daripada $r$ tabel $(0,834>0,127)$.

Selanjutnya dilakukan uji signifikansi, yaitu

1. Uji Rasio Likelihood

Nilai G merupakan skor -2 Log likelihood pada output SPSS. Berikut hasil output SPSS yang dimaksud. Tabel 2. Uji Rasio Likelihood

\begin{tabular}{|l|l|l|l|}
\hline Step & -2 Log likelihood & Cox and Snell $R$ Square & Nagelkerke $R$ Square \\
\hline 1 & 128.842 & .035 & .080 \\
\hline
\end{tabular}

Sumber data: output SPSS 25

Nilai G berdasarkan tabel 2 adalah 128,842. Berdasarkan tabel Chi-square (taraf nyata 5\% dan df = 4), nilai chi-square adalah 9,488. Oleh karena itu, $\mathrm{H}_{\mathrm{o}}$ ditolak disebabkan $\mathrm{G}>$ dari chi-square. Kesimpulan yang dapat diambil adalah paling tidak satu koefisien variabel independen dari model akan berpengaruh pada variabel dependen.

\section{Uji Wald}

Skor Wald digunakan untuk menguji signifikansi secara individual. Berikut output SPSS untuk nilai Wald.

Tabel 3 Uji Wald

\begin{tabular}{|c|c|c|c|c|c|c|}
\hline & B & S.E. & Wald & df & Sig. & Keterangan \\
\hline F & .039 & .044 & .780 & 1 & .377 & Tidak Signifikan \\
\hline P & .037 & .063 & .339 & 1 & .561 & Tidak Signifikan \\
\hline E & .017 & .036 & .210 & 1 & .647 & Tidak Signifikan \\
\hline D & -.092 & .056 & 2.664 & 1 & .103 & Tidak Signifikan \\
\hline
\end{tabular}

Sumber data: output SPSS 25

Nilai chi-square pada derajat bebas $=1$ dengan tingkat signifikansi 5\% adalah 3,841. Berdasarkan tabel 3, nilai W yang melebihi nilai chi-square tabel tidak ada. Hal ini memperlihatkan bahwa tidak ada variabel independen yang berpengaruh secara signifikan pada kepatuhan pajak dengan taraf nyata $5 \%$.

\section{Uji Goodness of fit test}

Tabel output SPSS pada nilai Hosmer-Lemeshow adalah sebagai berikut.

Tabel 4. Tabel Kontinjensi Hosmer-Lemeshow Test

\begin{tabular}{|c|l|c|l|c|c|}
\hline \multirow{2}{*}{$\mathrm{g}$} & \multicolumn{2}{|c|}{ Kepatuhan Pajak = Tidak Memiliki } & \multicolumn{2}{|c|}{ Kepatuhan Pajak = Memiliki } & Total \\
\cline { 2 - 6 } & Observasi & Prediksi & Observasi & Prediksi & \\
\hline 1 & 4 & 4.903 & 20 & 19.097 & 24 \\
\hline
\end{tabular}




\begin{tabular}{|l|l|l|l|l|l|}
\hline 2 & 2 & 3.055 & 22 & 20.945 & 24 \\
\hline 3 & 1 & 2.553 & 23 & 21.447 & 24 \\
\hline 4 & 2 & 2.182 & 22 & 21.818 & 24 \\
\hline 5 & 4 & 1.821 & 20 & 22.179 & 24 \\
\hline 6 & 2 & 1.619 & 22 & 22.381 & 24 \\
\hline 7 & 2 & 1.409 & 22 & 22.591 & 24 \\
\hline 8 & 2 & 1.172 & 22 & 22.828 & 24 \\
\hline 9 & 1 & .860 & 23 & 23.140 & 24 \\
\hline 10 & 0 & .425 & 22 & 21.575 & 22 \\
\hline
\end{tabular}

Sumber data: output SPSS 25

Tabel 5. Tabel Hosmer-Lemeshow Test

\begin{tabular}{|l|l|l|}
\hline Chi-square & df & Sig. \\
\hline 5.954 & 8 & .652 \\
\hline
\end{tabular}

Sumber data: output SPSS 25

Tabel 4. yang menunjukkan dari sepuluh observasi kepatuhan pajak dan tidak memiliki kepatuhan, nilai hasil observasi dan prediksi pada masing-masing pengamatan memiliki perbedaan yang tidak terlalu besar. Dengan demikian, persamaan regresi logistik biner dalam penelitian ini dianggap mampu memprediksi hasil pengamatan.

Tabel 5. menguatkan kesimpulan sebelumnya. Hal ini didasari oleh nilai chi-square HosmerLemeshow sebesar 5,954 yang kurang dari nilai tabelnya (skor chi-square dengan $\mathrm{g}=10$ sebesar 15,507). Apabila nilai hitung<nilai tabel, kesimpulannya adalah gagal tolak $\mathrm{H}_{0}$. Kemudian, nilai signifikansi sebesar 0,652 semakin menguatkan kegagalan dalam menolak $\mathrm{H}_{0}$. Dengan demikian, persamaan regresi logistik biner yang telah disusun layak digunakan dalam penelitian ini.

Tabel 6 Hasil Regresi Logistik Biner

\begin{tabular}{|c|c|c|c|c|c|c|}
\hline \multirow{4}{*}{ Variabel Independen } & \multicolumn{6}{|c|}{ Variabel Dependen $=$ Kepatuhan Pajak } \\
\hline & \multicolumn{6}{|c|}{ Regresi Logistik Biner } \\
\hline & \multicolumn{2}{|c|}{ Logit 1} & \multicolumn{2}{|c|}{ Logit 2} & \multicolumn{2}{|c|}{ Logit 3} \\
\hline & Koefisien & $\begin{array}{l}\text { Odds } \\
\text { Ratio }\end{array}$ & Koefisien & $\begin{array}{l}\text { Odds } \\
\text { Ratio }\end{array}$ & Koefisien & $\begin{array}{l}\text { Odds } \\
\text { Ratio }\end{array}$ \\
\hline fantasy items & & & 0,039 & 1,039 & & \\
\hline empathic concern items & $0,053 * *$ & 1,054 & 0,017 & 1,017 & & \\
\hline perspective-taking items & & & 0,037 & 1,037 & & \\
\hline personal distress items & & & $-0,092$ & 0,912 & & \\
\hline Multidimensi (total 4 variabel) & & & & & 0,024 & 1,024 \\
\hline Konstanta & $-0,346$ & 0,707 & 2,183 & 8,874 & $-1,009$ & 0,364 \\
\hline Pseudo R square & 0,0287 & & 0,0618 & & 0,0183 & \\
\hline Jumlah Responden & 238 & & 238 & & 238 & \\
\hline
\end{tabular}

Sumber data: hasil olahan penulis

Keterangan: ** menunjukkan taraf signifikansi $5 \%$.

Pengujian selanjutnya adalah analisis regresi logistik biner untuk mengetahui apakah sifat empati pada wajib pajak mempengaruhi kepatuhan dalam pembayaran pajak. Kemudian, pengujian dilakukan pada masing-masing dimensi dan uji simultan untuk mengetahui peubah yang signifikan. Berikut hasil uji regresi logistik biner.

Berdasarkan tabel $6, \mathrm{H}_{0}$ gagal ditolak pada model Logit 2 sesuai persamaan regresi logistik biner pada penelitian ini karena taraf nyata seluruh variabel independen di atas 5\%. Dengan demikian, $\mathrm{H}_{0}$ diterima yang berarti bahwa fantasy items, perspective-taking items, empathic concern items, dan personal distress items cenderung tidak mempengaruhi kepatuhan pajak secara bersama-sama. 


\section{PEMBAHASAN}

Penelitian ini membahas tentang apakah ada pengaruh sifat empati pada wajib pajak terhadap kepatuhan mereka dalam membayar pajak. Variabel yang diuji adalah empati dengan 4 (empat) dimensinya serta kepatuhan pajak. Variabel tersebut kemudian diuji dengan analisis regresi logistik biner. Sebelum diuji dengan regresi, model yang disusun telah diuji signifikansinya mengikuti teori Agresti (2003).

Pengujian regresi dilakukan sebanyak 3 (tiga) kali dengan variabel bebas yang berbeda tetapi variabel terikat yang sama, yaitu kepatuhan pajak. Hal ini bertujuan untuk mendapatkan prediktor yang signifikan dan mendapatkan persamaan regresi logistik biner yang paling menjelaskan variabel respon melalui nilai pseudo R square nya. Model Logit 1 memiliki 1 (satu) variabel independen, yaitu empathic concern items. Model Logit 2 memiliki 4 (empat) variabel independen, yaitu fantasy items, empathic concern items, perspective-taking items, dan personal distress items. Variabel independen Logit 3 adalah total nilai multidimensi karakteristik empati sesuai ukuran Davis (1983).

Berdasarkan Tabel 6., dari ketiga model Logit, hanya Logit 1 yang variabel independennya signifikan mempengaruhi variabel dependen. Variabel empathic concern items mempengaruhi kepatuhan pajak dengan taraf signifikansi 5\%. Namun, prediktor hanya dapat menjelaskan variabel respon sebesar 2,87\%. Nilai odds rasio sebesar 1,054 dapat digunakan untuk menginterpretasikan kecenderungan perbandingan antara jumlah individu yang termasuk patuh pajak dengan yang tidak (Agresti, 2003). Skor 1,054 menunjukkan bahwa peluang wajib pajak yang memiliki sifat empathic concern items akan lebih patuh sebesar 1,054 kali untuk membayar pajak dibanding dengan responden yang tidak memiliki sifat tersebut. Dengan kata lain, wajib pajak yang berkepribadian hangat dan peduli pada kesusahan orang lain cenderung lebih patuh dalam membayar pajak daripada yang tidak berkepribadian seperti tersebut.

Hasil yang berbeda muncul ketika variabel empathic concern items diuji bersama prediktor lain dalam model regresi logistik biner. Tabel 6. model Logit 2 menunjukkan bahwa tidak ada variabel independen yang berpengaruh secara signifikan terhadap variabel dependen pada tingkat signifikansi berapapun. Variabel personal distress items mendekati taraf nyata $10 \%$ namun masih termasuk dalam kriteria tidak signifikan (nilai $P$-value sebesar $10,3 \%$ ).

Berdasarkan model Logit 2, persamaan regresi logistik yang dihasilkan adalah sebagai berikut.

$$
\log \left[\frac{P}{1-P}\right]=2,183+0,039 \mathrm{~F}+0,017 \mathrm{E}+0,037 \mathrm{P}-0,092 \mathrm{D}+\mathrm{e}
$$

Persamaan di atas merupakan model regresi yang digunakan dalam penelitian ini. Namun demikian, hasil regresi menunjukkan bahwa dari ke-empat variabel bebas tidak ada yang signifikan mempengaruhi variabel terikatnya.

Model Logit 3 merupakan nilai gabungan dari ke-empat variabel independen. Hasil uji regresi menunjukkan bahwa variabel tersebut tidak berpengaruh secara signifikan terhadap variabel responnya. Hasil tersebut selaras dengan model Logit 2.

Secara umum, hasil analisis regresi logistik biner dalam penelitian ini sejalan dengan penelitian Calvet and Alm (2017) bahwa empati dapat meningkatkan kepatuhan pajak. Hasil penelitian ini memiliki kontribusi yang penting dalam peningkatan kepatuhan wajib pajak dalam membayar pajaknya. Pemerintah dapat menyusun regulasi yang mendukung munculnya empathic concern items di masyarakat mengingat pentingnya sifat ini dalam kepatuhan pajak. Ditambah lagi, para peneliti telah menyimpulkan bahwa empati dapat ditingkatkan melalui cara-cara tertentu (Dewi, Pratisti, and Prasetyaningrum, 2019; Kelm, Womer, Walter, and Feudtner, 2014; Reilly, Trial, Piver, and Schaff, 2012). Contoh peningkatan empati adalah Iklan naratif yang mempromosikan perilaku tertentu (De Vooght and Hudders, 2021). Selain itu, simulasi berupa role play dengan memainkan peran tertentu juga dapat meningkatkan empati (Kato, 2021). 


\section{KESIMPULAN}

Penelitian ini berfokus pada variabel independen yang diduga dapat mempengaruhi kepatuhan pajak wajib pajak, diantaranya fantasy items, empathic concern items, perspective-taking items, dan personal distress items. Berdasarkan analisis regresi logistik biner yang telah dilakukan, variabel empathic concern items berpengaruh secara signifikan terhadap kepatuhan pajak apabila diuji secara mandiri. Nilai odds rasio sebesar 1,054 menunjukkan bahwa peluang wajib pajak yang memiliki sifat empati akan lebih patuh pajak 1,054 kali dibanding dengan responden yang tidak memiliki empathic concern items. Dengan kata lain, responden yang memiliki sifat tersebut akan cenderung lebih patuh dalam membayar pajak daripada yang tidak memiliki sifat tersebut. Berdasarkan hasil penelitian ini, pemerintah dapat membuat kebijakan-kebijakan agar sifat empathic concern items meningkat di kalangan masyarakat. Namun demikian, apabila diuji secara bersama-sama, variabel bebas berupa fantasy items, empathic concern items, perspective-taking items, dan personal distress items tidak mempengaruhi secara signifikan kepatuhan pajak mereka. Penelitian tentang dampak empati terhadap kepatuhan pajak belum dilirik oleh akademisi di Indonesia. Penelitian tentang perilaku, terutama empati, dapat ditingkatkan mengingat bahwa perilaku juga mempengaruhi kepatuhan pajak. Hal ini perlu dilakukan sebagai bahan pembuatan kebijakan pemerintah terkait peningkatan kepatuhan pajak sehingga program pemerintah tidak hanya berfokus pada faktor ekonomi tetapi juga faktor non ekonomi.

\section{REFERENSI}

Agresti, A. (2003). Categorical data analysis (Vol. 482). John Wiley \& Sons.

Andreas, \& Savitri, E. (2015). The Effect of Tax Socialization, Tax Knowledge, Expediency of Tax ID Number and Service Quality on Taxpayers Compliance with Taxpayers Awareness as Mediating Variables. Procedia - Social and Behavioral Sciences, 211(September), 163-169. https://doi.org/10.1016/j.sbspro.2015.11.024

Ariyanto, D., Andayani, G. A. P. W., \& Putri, I. G. A. M. A. D. (2020). Influence of Justice, Culture and Love of Money Towards Ethical Perception on Tax Evasion with Gender as Moderating Variable. Journal of Money Laundering Control, 23(1), 245-266. https://doi.org/10.1108/JMLC06-2019-0047

Calvet, R., \& Alm, J. (2017). Empathy, sympathy, and tax compliance. Journal of Economic Psychology, 40(February 2014), 62-82.

Chambers, J. K. (1996). Quantitative Applications in the Social Sciences. Journal of English Linguistics, Vol. 24, pp. 160-164. https://doi.org/10.1177/007542429602400208

Davis, M. H. (1983). A Multidimensional Approach to Individual Differences in Empathy. Journal of Personality and Social Psychology, 44(1), 113-126. https://doi.org/10.1037/0022-3514.44.1.113

De Vooght, E., \& Hudders, L. (2021). Narrating Pain to Make You Understand: Using Novel Metaphors to Increase Empathy. 19th ICORIA.

Dewi, Y. T., Pratisti, W. D., \& Prasetyaningrum, J. (2019). The Effect of Roleplay to Increase Empathy Toward Students with Disruptive Classroom Behavior. International Summit on Science Technology and Humanity (ISETH2019), 210-219.

Direktorat Jenderal Pajak (2021). Laporan Kinerja Direktorat Jenderal Pajak 2020.

Edina, M. (2020). The role of empathy, anxiety and personality in purchasing decisions caused by advertising. Annals of the University of Oradea. Economic Science, 29(1), 376-386.

Guthridge, M., \& Giummarra, M. J. (2021). The Taxonomy of Empathy: A Meta-definition and the Nine Dimensions of the Empathic System. Journal of Humanistic Psychology.

Hosmer, D. W., Lemeshow, S., \& Sturdivant, R. X. (2013). Applied Logistic Regression Analysis. In John Wiley \& Sons, Inc. (Third Edit, Vol. 3). https://doi.org/10.2307/1270433

Iyer, R., Hosmer, D. W., \& Lemeshow, S. (1991). Applied Logistic Regression. The Statistician, 40(4), 458. https://doi.org/10.2307/2348743

Kamil, N. I. (2015). The Effect of Taxpayer Awareness, Knowledge, Tax Penalties and Tax Authorities Services on the Tax Complience:(Survey on the Individual Taxpayer at Jabodetabek \& Bandung). Research Journal of Finance and Accounting, 6(2), 104-111. 
Kato, N. (2021). Applying a Program Increasing Empathy in Expectant Couples to Adolescent Mental Health Promotion. JMA Journal, 4(4), 439-440.

Kelm, Z., Womer, J., Walter, J. K., \& Feudtner, C. (2014). Interventions to cultivate physician empathy: A systematic review. BMC Medical Education, 14(1), 1-11. https://doi.org/10.1186/1472-6920-14-219

Lipps, T., \& Sanborn, H. C. (1926). Psychological Studies.

Malau, Y. N., Gaol, T. L., Giawa, E. N., \& Juwita, C. (2021). Pengaruh Kesadaran Wajib Pajak, Pengetahuan Pajak, Sanksi Pajak Dan Pelayanan Fiskus Terhadap Kepatuhan Wajib Pajak Kendaraan Bermotor di Kota Medan. Ekonomis: Journal of Economics and Business, 5(2), 551. https://doi.org/10.33087/ekonomis.v5i2.414

Manual, V., \& Xin, A. Z. (2016). Impact of Tax Knowledge, Tax Compliance Cost, Tax Deterrent Tax Measures towards Tax Compliance Behavior: A Survey on Self-employed Taxpayers in West Malaysia. Electronic Journal of Business and Management, 1(1), 56-70.

McDougall, W. (1908). An Investigation of the Colour Sense of Two Infants. British Journal of Psychology, 1904-1920(4), 338-352.

Mead, G. H. (1934). Mind, Self, and Society. The American Journal of Psychology, 48(3), 541. https://doi.org/10.2307/1415920

Moreno-Poyato, A. R., \& Rodríguez-Nogueira, Ó. (2021). The association between empathy and the nurse-patient therapeutic relationship in mental health units: a cross-sectional study. Journal of Psychiatric and Mental Health Nursing, 28(3), 335-343.

Nugrahani, R. F., \& Andriani, F. (2020). The Effect of Service Learning to Improve Empathy to Bully in Primary School. Proceedings of the 3rd International Conference on Psychology in Health, Educational, Social, and Organizational Settings - ICP-HESOS, 5-11.

Pawama, S. D., Sondakh, J. J., \& Warongan, J. D. L. (2021). Pengaruh kesadaran wajib pajak, transparansi pajak dan Penggunaan aplikasi e-filing terhadap kepatuhan wajib pajak orang pribadi pada umkm di kota Manado. Jurnal Riset Akuntansi Dan Auditing "GOODWILL," 12(1), 38-50.

Piaget, J. (1932). The moral development of the child. London: Kegan, Paul, Trench, Trubner \& co.

Reilly, J. M., Trial, J., Piver, D. E., \& Schaff, P. B. (2012). Using Theater to Increase Empathy Training in Medical Students. Journal for Learning through the Arts: A Research Journal on Arts Integration in Schools and Communities, 8(1). https://doi.org/10.21977/d9812646

Saleh, A. M., Rukmana, R., \& Rahayu, S. J. (2021). Pengaruh Kesadaran Wajib Pajak dan Pemahaman Wajib Pajak terhadap Kepatuhan Wajib Pajak Orang Pribadi pada KPP Pratama Makassar Selatan. YUME: Journal of Management, 4(2), 543-553. https://doi.org/10.37531/yume.vxix.344

Sekaran, U., \& Bougie, R. (2016). Research methods for business.

Siregar, D. L. (2017). Pengaruh Kesadaran Wajib Pajak dan Sanksi Pajak terhadap Kepatuhan Wajib Pajak Orang Pribadi Pada Kantor Pelayanan Pajak Pratama Batam. Journal of Accounting \& Management Innovation, 2(2), 119-128. https://doi.org/10.47860/economicus.v14i2.196

Stepien, K. A., \& Baernstein, A. (2006). Educating for empathy: A review. Journal of General Internal Medicine, 21(5), 524-530. https://doi.org/10.1111/j.1525-1497.2006.00443.x

Sularsih, H., \& Wikardojo, S. (2021). Moralitas dan kesadaran terhadap kepatuhan wajib pajak UMKM dengan memanfaatkan fasilitas perpajakan dimasa pandemi Covid-19. Jurnal Paradigma Ekonomika Vol.16. No.2, April - Juni 2021, 16(2), 225-234.

Sumartaya, D., \& Hafidiah, A. (2014). The Influence of Taxpayer's Awareness and Tax Morale toward Tax Evasion. International Journal of Business, Economics and Law, 5(1), 60-68.

Wardani, D. K., \& Rumiyatun, R. (2017). Pengaruh Pengetahuan Wajib Pajak, Kesadaran Wajib Pajak, Sanksi Pajak Kendaraan Bermotor, Dan Sistem Samsat Drive Thru Terhadap Kepatuhan Wajib Pajak Kendaraan Bermotor. Jurnal Akuntansi, 5(1), 15. https://doi.org/10.24964/ja.v5i1.253 